\title{
Investigation of the association between metabolic syndrome and breast cancer patients
}

\author{
Delaram Eskandari (1), Niloofar Khodabandehloo (2), Abbas Gholami (3), Hosein \\ Samadanifard (1), Alireza Hejrati (3)
}

(1) Department of endocrinology, School of Medicine, Hazrat-e Rasool Hospital, Iran University of Medical Sciences. Tehran, Iran; (2) School of Medicine, Hazrat-e Rasool Hospital, Iran University of Medical Sciences. Tehran, Iran; (3) Department of Internal Medicine, School of Medicine, Hazrat-e Rasool Hospital, Iran University of Medical Sciences. Tehran, Iran

This article is distributed under the terms of the Creative Commons Attribution Noncommercial License (CC BY-NC 4.0) which permits any noncommercial use, distribution, and reproduction in any medium, provided the original author(s) and source are credited.

\begin{abstract}
One of the most serious cancers among women is breast cancer. This disease is the first reason for the death of women due to cancer. Increasing breast cancer risk may associate with many factors including genetic, reproductive factors, people's lifestyle, metabolic syndrome (MS) and hormones. MS has been known as a risk factor for prostate, pancreatic, breast and colorectal cancers. The purpose of this review is to identify the relationship between MS components and breast cancer individually. This study was performed by researching electronic database references including PubMed, Google Scholar, CINAHL ProQuest, and web of science through 2019. The effect of MS with its components and breast cancer was reported in many studies. Nevertheless, a thorough understanding of the mechanisms involved remains a challenge. However, one can take several preventive measures, including a proper diet, which is one of the most important determinants of metabolic status. Also, general preventive recommendations are including reducing alcohol consumption, red meat and total fat in the diet. Moreover, increasing the consumption of vegetable and fruit reduce the proportion of MS patients to improve the outcome of breast cancer patients.
\end{abstract}

Key Words: Breast cancer, metabolic syndrome, electronic database, natural products.

Eur J Transl Myol 30 (3): xxl-xx7, 2020

Breast cancer is one of the most serious diseases among women in the world. This disease is the first reason for the death of women due to cancer. Increasing breast cancer risk may be associated with many factors including genetic, reproductive and hormonal parameters, metabolic syndrome (MS) and people lifestyle. ${ }^{1,2} \mathrm{MS}$ is a cluster of metabolic abnormality that happens to people with disordered sensitivity to insulin. ${ }^{3}$ It is described with the existence of factors including the increase of triglycerides in the blood, abdominal obesity, increasing fasting glucose and high pressure of blood. ${ }^{4}$ MS is known as a danger for many cancers such as those of prostate, pancreas, breast and colorectal region. ${ }^{5-10}$ Studies show that, in women age above 18 years, there is a mild positive dependency between breast cancer and MS. ${ }^{11}$ Moreover, many of these studies indicate a positive relationship with diabetes, breast cancer, ${ }^{12-18}$ and obesity. ${ }^{2,19,20}$ Additionally, some studies show dyslipidemia and hypertension as danger agents in breast cancer. ${ }^{11,21-24}$ Despite single MS components cannot be powerfully related to the advancement of breast cancer, their mixture can enhance the venture. ${ }^{8,9}$ The main objective of this paper is to study relationship among the individual MS components and breast cancer.

\section{Definition and Prevalence of Metabolic Syndrome}

The definition of MS began from 2001,25 then the concept of integrated definition has been fixed (Table 1). ${ }^{4}$ For populations of Caucasian, in men and women 102 and $88 \mathrm{~cm}$ waist respectively, is generally chosen as an evidence of abdominal obesity. Diagnosis of MS complies when 3 of the 5 criteria exist. ${ }^{4,25}$ The spread of MS in the west is among $20-25 \%$ of adult people, while in old people it ranges from 40 to $45 \%^{26,27}$. MS also increases risks of cardiovascular diseases. ${ }^{28}$

\section{Association of breast cancer and diabetes}

Many clinical studies showed diabetes and breast cancer correlation. In one study in the United States 1.2 million patients (588321 were women) were enrolled and studied 
Table 1: Criteria for Clinical Diagnosis of Metabolic Syndrome ${ }^{4}$

\begin{tabular}{|c|c|}
\hline Measure & Categorical cut points \\
\hline $\begin{array}{l}\text { Elevated waist circumference } \\
\text { Elevated triglycerides (drug treatment for elevated } \\
\text { triglycerides is an alternate indicator) }\end{array}$ & $\begin{array}{l}\text { population- and country-specific definitions } \\
\geq 150 \mathrm{mg} / \mathrm{dL}(1.7 \mathrm{mmol} / \mathrm{L})\end{array}$ \\
\hline $\begin{array}{l}\text { Reduced HDL-cholesterol (drug treatment for reduced } \\
\text { HDL- cholesterol is an alternate indicator) }\end{array}$ & $\begin{array}{l}\leq 40 \mathrm{mg} / \mathrm{dL}(1.0 \mathrm{mmol} / \mathrm{L}) \text { in males; } \\
\leq 50 \mathrm{mg} / \mathrm{dL}(1.3 \mathrm{mmol} / \mathrm{L}) \text { in females }\end{array}$ \\
\hline $\begin{array}{l}\text { Elevated blood pressure (antihypertensive drug treatment } \\
\text { in a patient with a history of hypertension is an alternate } \\
\text { indicator) }\end{array}$ & $\begin{array}{l}\text { Systolic } \geq 130 \text { and/or diastolic } \\
\geq 85 \mathrm{~mm} \mathrm{Hg}\end{array}$ \\
\hline $\begin{array}{l}\text { Elevated fasting glucose (drug treatment for elevated } \\
\text { glucose is an alternate indicator) }\end{array}$ & $\geq 100 \mathrm{mg} / \mathrm{dl}$ \\
\hline
\end{tabular}

for 6 years (1982-1988). It was shown that diabetic women with breast cancer died more than women without diabetes. ${ }^{29}$ Some meta-analyses have investigated this relation in details ${ }^{13,30-32}$. Much research confirmed the role of diabetes on breast cancer level, increasing hospitalization and decreasing illness-free duration. ${ }^{33-35}$ Insulin resistance of Type 2 diabetes may cause hyperglycemia that support cell differentiation and proliferation. Hyperinsulinemia can increase mitogenicity. The increase of circulating estrogens may favor breast cancer development. ${ }^{30}$ Insulin can have direct effects on epithelial cells and thus supporting tumorigenesis. ${ }^{36},{ }^{37}$ Insulin receptor is more concentrated in breast cancer tissue than in healthy tissue. ${ }^{38}$ Insulin can act via an insulin-like growth factor (IGF) system that is a main breast cancer pathway. Increased of IGF-1 level and binding of insulin-like growth factor protein 3 (IGFBP3) level may increase risk of breast cancer. ${ }^{39,40}$ Much research investigated the relationship between therapy for type 2 diabetes and breast cancer. Metformin is a biguanide medicine cause to decrease hyperinsulinemia and hyperglycemia by increasing muscle glucose absorption. It is thought metformin independent of insulin has a desirable effect on breast cancer prevention and treatment. ${ }^{41,42}$ In 2018 Tang et al investigated 12 articles about metformin and breast cancer relationship in a systematic review. They showed non statistically significant improvement of T2D and breast cancer patients with metformin. ${ }^{43}$ The multivariate investigation was performed by Bosco et al. showed metformin used for less than one year may decrease breast cancer incidence ${ }^{42}$. Research in 2018 evaluated the breast cancer risk for aged women treated with metformin or sulfonylureas. No reduction of breast cancer risk was showed adding metformin to the clinical alternative. ${ }^{44}$ On the other hand, clinical trials show metformin efficacy when used before breast cancer surgery. ${ }^{45}$ Recently, relation between PPAR $\gamma$ (a nuclear hormone receptor) and breast cancer have been shown. Reducing PPAR $\gamma$ expression causes higher tumor grade and development of the disease. ${ }^{46}$ But in one study with 22 patients, a PPAR $\gamma$ agonist didi not induced any reaction in patients. ${ }^{47}$ In contrast, using long term of insulin glargine may increase breast cancer risk. ${ }^{48}$ In summary, managements of diabetes can have the same impact as diabetes itself, thus randomized controlled trials are needed. In summary, published data demonstrate that type 2 diabetes increase breast cancer risk. ${ }^{49}$ Better ndersatnding of the involved mechanisms may open the way to find new drugs that may be useful to establish stronger preventive measures.

\section{Obesity and breast cancer}

According to several epidemiological studies, obesity before menopause protects for breast cancer ${ }^{50}$. On the contrary, obesity after menopause may increase breast cancer risks ${ }^{49,51}$.

In particular, triple-negative breast cancer. ${ }^{52,53}$

Indeed, adipokines and breast cancer relations have been studied. Leptin levels and obesity levels have positive effect on each other, while lower leptin levels are associated with increased obesity. One study has shown that leptin and its receptor expression in adipose tissue were similar to that of obesity in breast cancer. ${ }^{54-56}$

\section{Breast cancer and hypertension}

Recent studies have shown that increased blood pressure (hypertension) is a risk for breast cancer, ${ }^{24,57,58}$ but there are contradictory findings. ${ }^{56,58,59}$ One study found that diuretics increased breast cancer risk in hypertension. ${ }^{60}$ In another study, Li CI et al. claims that there was low statistical correlation between these two events ${ }^{61}$ High blood pressure during pregnancy or pre-eclampsia seem to be breast cancer risks, but another study found that that high blood pressure (pre-eclampsia) reduces the chance of breast cancer risk of 20-30\%, through a lower concentration of insulin-like growth factor and estrogen and a higher amount of androgens and human chorionic gonadotropin in women with pre-eclampsia. ${ }^{62}$ Anyhow, the relationship between hypertension, utilization of relevant drugs and breast cancer continues to be very controversial. 
Western Lifestyle (Overnutrition, Physical inactivity)

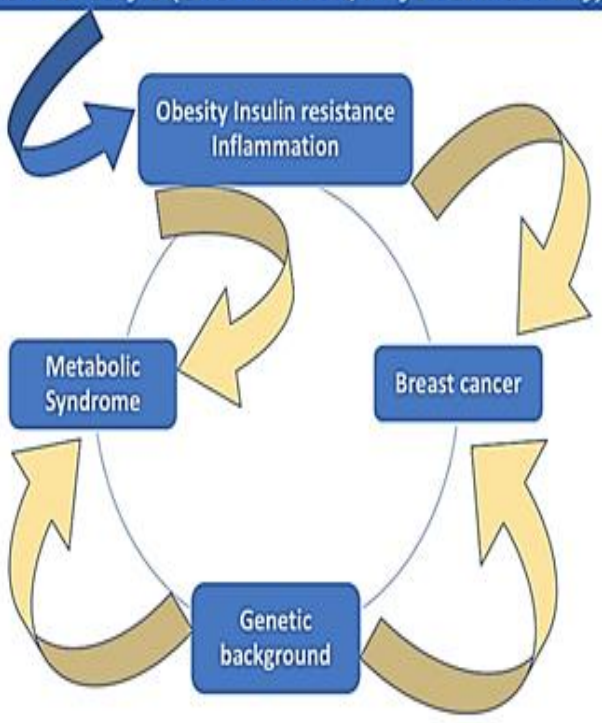

Fig 1. The diagram of the connection between metabolic syndrome and breast cancer ${ }^{27}$

\section{Breast cancer and dyslipidemia}

Dyslipidemia is another widely discussed risk factor. Low HDL-cholesterol is a risk factor for cardiovascular illness, but may cause cancer in other parts of the body, ${ }^{63}$ but because of differences in the populations and methods of analysis, conclusions are mixed ${ }^{64-66} \mathrm{Kim}$ et al. have shown that HDL has a protective effect on some postmenopausal women with breast cancer, ${ }^{67}$ but Kucharska et al. in a prospective study of 15.792 men and women found that there was only a moderate dependence of breast cancer increased risk and low premenopausal HDL-cholesterol free, number of live births, race, age, age at menarche, smoking status and BMI ${ }^{68}$ All cancer cells need fatty acids (FA) to grow and survive and obstruction of de novo FA synthesis in rat models has resulted in anticancer effects. ${ }^{56}$ In summary, lipids and lipoproteins have an impact on cardiovascular disease and may have also an impact in breast cancer being active molecules with high effects rather than idle means of energy storage. Changes in lifestyle, as advised for cardiovascular disease prevention, may be important to prevent also breast cancer deaths.

\section{Breast cancer and Metabolic Syndrome}

MS is a mixture of metabolic disturbances such as insulin resistance, dyslipidemia, hypertension, visceral obesity, and raised blood sugar. As a unique medical risk, MS has been studied with breast cancer. ${ }^{56,69-71}$ The odds ratios of breast cancer after menopausal were 1.33 (95\% CI 1.09$1.62)$ to diabetes, $1.19(95 \%$ CI $1.07-1.33)$ to hypertension, $\quad 1.08 \quad(95 \% \quad \mathrm{CI} \quad 0.95-1.22)$ to hyperlipidemia, 1.26 (95\% CI $1.11-1.44$ ) to $\mathrm{BMI} \geq 30$ $\mathrm{kg} / \mathrm{m} 2$, and 1.22 (95\% CI 1.09-1.36) to waist perimeter $\geq 88 \mathrm{~cm}$. In women with metabolic syndrome, the risk of breast cancer after menopausal is significantly increased (OR 1.75, 95\% CI 1.37-2.22), which is higher at an older age (OR 3.04, 95\% CI 1.75-5.29, at age $\geq 70$ years). ${ }^{5}$ Metabolic syndrome presents many changes in the body's metabolism. Below, we examine the possible mechanisms increasing the risk of breast cancer. One of the molecules presumed to mediated the metabolic syndrome risk is the plasminogen activator inhibitor-1 (PAI-1). This protein is known as a physiological inhibitor of urokinase (uPA). On the other hand, increased levels of PAI-1 are paradoxically associated with poor prognosis in breast cancer. ${ }^{72}$ In fact, Stern introduced the hypothesis of a "common soil" affected by metabolic syndrome, defined as chronic inflammation and insulin resistance, that is suspected to be related to breast cancer ${ }^{73}$ Further evidence is presented in Figure 1. ${ }^{27}$ The reason for high levels of insulin in cancer progression, as well as mortality, is that insulin appears to have mitogenic, anti-apoptotic and angiogenic properties. ${ }^{74}$ Moreover, researchers have found insulin to incite the synthesis of insulin-like growth factor 1 (IGF1) and to Poor link to the IGF-1 receptor. Commonly, insulin-IGF-1 signaling is up-regulated in tumor cells, as it is up-regulated in obesity, leading to activation of the oncogenic Ras-MAPK and PI3K-Akt pathways (MAPK - mitogen-activated protein kinase, PI3K phosphoinositide 3-kinase). Additional, the Akt pathway stimulates the rapamycin mammalian target rapamycin (mTOR), all together known mechanisms of the tumor cell growth. ${ }^{27,75}$ In breast cancer, adipose tissue is a major part of the tumor. Due to the interaction between cancer cells and the adipose surrounding fat, it is known as cancer-associated fat (CAA) that by its own secretion sustain tumor growth. ${ }^{27}$ Direct contact of these two cells destroys differentiation markers and enhances expression of inflammatory cytokines including IL-6 and plasminogen activator type 1 inhibitor (PAI-1). ${ }^{76}$ Reduction of fat tissue, especially visceral, may reduce MS features. So, weight loss obtained with regular exercise seems to decrease chronic inflammation and insulin resistance. ${ }^{77}$ The achievement of these goals were recently investigated. ${ }^{77}$ These studies show that weight loss decreases markers of cancer progression and the progression of the tumor. ${ }^{27,78,79}$

Another option for breast cancer prevention and for improvement of its prognosis is the Mediterranean diet. ${ }^{80,81}$ Together with other food supplements, Mediterranean diet was reported to be effective also in pediatrics periods. ${ }^{82-84}$

\section{Conclusions}

In this short review, we examined the components of the metabolic syndrome in relation to breast cancer, as they are reported in many studies. Nevertheless, a thorough understanding of the mechanisms involved remains a challenge. Among a number of preventive measures, proper diet, that seems to be one of the most effectives 
determinants of metabolic status, ought to be considered. General preventive recommendations are to reduce alcohol, red meat and total fat in the diet, while increasing consumption of vegetables and fruits. These measures will reduce thenumber of MS patients, thus improving outcomes of breast cancer. ${ }^{53,56}$

\section{List of acronyms}

MS - Metabolic syndrome

PPAR $\gamma$ - Peroxisome proliferator-activated receptor $\gamma$

FA - fatty acids

BMI - Body mass index

PAI-1 - Plasminogen activator inhibitor-1

MAPK - Mitogen-activated protein kinase

PI3K - Phosphoinositide 3-kinase

CAA - Cancer-Associated Adipocytes.

\section{Authors contributions}

DE, NKH, AGH, HS, AH drafted the manuscript and were responsible for literature review, participated in the conception and design of the work, and approved the final typescript.

\section{Acknowledgments None.}

Funding No funding was obtained for this study.

\section{Conflict of Interest}

The authors have no conflicts to disclose.

\section{Ethical Publication Statement}

We confirm that we have read the Journal's position on issues involved in ethical publication and affirm that this report is consistent with those guidelines.

\section{Corresponding Author}

Alireza Hejrati, Department of Internal Medicine, School of Medicine, Hazrat-e Rasool Hospital, Iran University of Medical Sciences. Tehran, Iran. Tel: +98 21 64352474. ORCID iD: 0000-0003-0087-8385

Email: Hejrati.a@iums.ac.ir

\section{E-mails of co-authors}

Delaram Eskandari: Eskandari.d@iums.ac.ir ORCID iD: 0000-0003-2524-2367

Niloofar Khodabandehloo: khodabandehloo.n@iums.ac.ir

ORCID iD: 0000-0002-0307-6014

Abbas Gholami: gholami.ab@iums.ac.ir

ORCID iD: 0000-0002-7033-7624

Hosein Samadanifard: dr_samadanifard@yahoo.com ORCID iD: 0000-0002-8015-3466

\section{References}

1. Ferlay J, Soerjomataram I, Dikshit R, et al. Cancer incidence and mortality worldwide: sources, methods and major patterns in GLOBOCAN 2012. Int J Cancer 2015;136:E359-86.
2. Wani B, Aziz SA, Ganaie MA, Mir MH. Metabolic Syndrome and Breast Cancer Risk. Indian J Med Paediatr Oncol 2017;38:434-439.

3. Riccardi G, Rivellese A. Dietary treatment of the metabolic syndrome - the optimal diet. Br J Nutr $2000 ; 83:$ S143-8.

4. Alberti KG, Eckel RH, Grundy SM, et al. Harmonizing the metabolic syndrome: a joint interim statement of the international diabetes federation task force on epidemiology and prevention; national heart, lung, and blood institute; American heart association; world heart federation; international atherosclerosis society; and international association for the study of obesity. Circulation 2009;120:1640-5.

5. Esposito K, Chiodini P, Capuano A, et al. Metabolic syndrome and postmenopausal breast cancer: systematic review and meta-analysis. Menopause 2013;20:1301-9.

6. Esposito K, Chiodini P, Capuano A, et al. Effect of metabolic syndrome and its components on prostate cancer risk: meta-analysis. J Endocrinol Invest 2013;36:132-9.

7. Esposito K, Chiodini $\mathrm{P}$, Capuano $\mathrm{A}$, et al. Colorectal cancer association with metabolic syndrome and its components: a systematic review with meta-analysis: Endocrine 2013;44:634-47.

8. Osaki Y, Taniguchi S-i, Tahara A, Okamoto M, Kishimoto T. Metabolic syndrome and incidence of liver and breast cancers in Japan. Cancer Epidemiol 2012;36:141-7.

9. Rosato V, Bosetti C, Talamini R, et al. Metabolic syndrome and the risk of breast cancer in postmenopausal women. Ann Oncol 2011;22:2687-92.

10. Rosato V, Tavani A, Bosetti C, et al. Metabolic syndrome and pancreatic cancer risk: a case-control study in Italy and meta-analysis. Metabolism 2011;60:1372-8.

11. Bhandari R, Kelley GA, Hartley TA, Rockett IR. Metabolic syndrome is associated with increased breast cancer risk: a systematic review with metaanalysis. Int J Breast Cancer 2014;2014:189384.

12. Michels KB, Solomon CG, Hu FB, et al. Type 2 diabetes and subsequent incidence of breast cancer in the Nurses' Health Study. Diabetes Care 2003;26:1752-8.

13. Larsson SC, Mantzoros CS, Wolk A. Diabetes mellitus and risk of breast cancer: a meta-analysis. Int J Cancer 2007; 121:856-62.

14. Goodman MT, Cologne JB, Moriwaki H, et al. Risk factors for primary breast cancer in Japan: 8-year follow-up of atomic bomb survivors. Prev Med 1997;26:144-53.

15. Weiderpass E, Gridley G, Persson I, et al. Risk of endometrial and breast cancer in patients with diabetes mellitus. Int J Can 1997;71:360-3.

16. Wideroff L, Gridley G, Chow W-H, et al. Cancer incidence in a population-based cohort of patients 
hospitalized with diabetes mellitus in Denmark. J Nation Can Instit 1997;89:1360-5.

17. Jee SH, Ohrr H, Sull JW, et al. Fasting serum glucose level and cancer risk in Korean men and women. JAMA 2005;293:194-202.

18. Boyle P, Boniol M, Koechlin A, et al. Diabetes and breast cancer risk: a meta-analysis. $\mathrm{Br} \mathrm{J}$ Cancer 2012;107:1608-17.

19. Van den Brandt PA, Spiegelman D, Yaun S-S, et al. Pooled analysis of prospective cohort studies on height, weight, and breast cancer risk. Am J Epidemiol 2000;152:514-27.

20. Morimoto LM, White E, Chen Z, et al. Obesity, body size, and risk of postmenopausal breast cancer: the Women's Health Initiative (United States). Cancer Causes Control 2002;13:741-51.

21. Tournberg S, Holm L, Carstensen J. Breast cancer risk in relation to serum cholesterol, serum betalipoprotein, height, weight, and blood pressure. Acta Oncol 1988;27:31-7.

22. Soler M, Chatenoud L, Negri E, et al. Hypertension and hormone-related neoplasms in women. Hypertension 1999;34:320-5

23. Manjer J, Kaaks R, Riboli E, Berglund G. Risk of breast cancer in relation to anthropometry, blood pressure, blood lipids and glucose metabolism: a prospective study within the Malmö Preventive Project. Eur J Cancer Prev 2001;10:33-42.

24. Peeters PH, van Noord PA, Hoes AW, et al. Hypertension and breast cancer risk in a 19-year follow-up study (the DOM cohort). J Hypertens 2000;18:249-54.

25. Detection EPO. Executive summary of the third report of the National Cholesterol Education Program (NCEP) expert panel on detection, evaluation, and treatment of high blood cholesterol in adults (adult treatment panel III). JAMA 2001;285:2486-497.

26. Ford ES, Giles WH, Dietz WH. Prevalence of the metabolic syndrome among US adults: findings from the third National Health and Nutrition Examination Survey. JAMA 2002;287:356-9.

27. Hauner D, Hauner H. Metabolic syndrome and breast cancer: is there a link? Breast Care 2014;9:277-81.

28. Eckel RH, Grundy SM, Zimmet PZ. The metabolic syndrome. The Lancet. 2005;365:1415-28.

29. Coughlin SS, Calle EE, Teras LR, et al. Diabetes mellitus as a predictor of cancer mortality in a large cohort of US adults. Am J Epidemiol 2004;159:1160-7.

30. Xue F, Michels KB. Diabetes, metabolic syndrome, and breast cancer: a review of the current evidence. Am J Clin Nutr 2007;86:s823-35.

31. Peairs KS, Barone BB, Snyder CF, et al. Diabetes mellitus and breast cancer outcomes: a systematic review and meta-analysis. J Clin Oncol 2011;29:40-6.
32. Dibaba DT, Ogunsina K, Braithwaite D, et al. Metabolic syndrome and risk of breast cancer mortality by menopause, obesity, and subtype. Breast Cancer Res Treat 2019;174:209-218.

33. Yancik R, Wesley MN, Ries LA, et al. Effect of age and comorbidity in postmenopausal breast cancer patients aged 55 years and older. JAMA 2001;285:885-92.

34. Ayeni O, Joffe M, Cubasch H, et al. Prevalence of comorbidities in women with and without breast cancer in Soweto, South Africa: Results from the SABC study. S Afr Med J 2019;109:264-271.

35. Lega IC, Austin PC, Fischer HD, et al. The impact of diabetes on breast cancer treatments and outcomes: a population-based study. Diabetes Care 2018;41:755-761.

36. Du W, Simon MS. Racial disparities in treatment and survival of women with stage I-III breast cancer at a large academic medical center in metropolitan Detroit. Breast Cancer Res Treat 2005;91:243-8.

37. Chang YS, Seo E-K, Gyllenhaal C, Block KI. Panax ginseng: a role in cancer therapy? Integr Cancer Ther 2003;2:13-33. Review.

38. Papa V, Pezzino V, Costantino A, et al. Elevated insulin receptor content in human breast cancer. $\mathrm{J}$ Clin Invest 1990;86:1503-10.

39. Sachdev D, Yee D. The IGF system and breast cancer. Endocrine-related cancer 2001;8:197-209.

40. Renehan AG, Harvie M, Howell A. Insulin-like growth factor (IGF)-I, IGF binding protein-3, and breast cancer risk: eight years on. Endocr Relat Cancer. 2006;13:273-8.

41. Vazquez-Martin A, Oliveras-Ferraros C, Del Barco $\mathrm{S}$, et al. If mammalian target of metformin indirectly is mammalian target of rapamycin, then the insulinlike growth factor-1 receptor axis will audit the efficacy of metformin in cancer clinical trials. J Clin Oncol. 2009;27:e207-9; author reply e210.

42. Bosco JLF, Antonsen S, Sørensen HT, et al. Metformin and incident breast cancer among diabetic women: a population-based case-control study in Denmark. Cancer Epidemiol Biomarkers Prev 2011;20:101-11.

43. Tang GH, Satkunam M, Pond GR, et al. Association of metformin with breast cancer incidence and mortality in patients with type II diabetes: A gradeassessed systematic review and meta-analysis. Cancer Epidemiol Biomarkers Prev 2018;27:627635.

44. Hong J-L, Funk MJ, Buse J, et al. Comparative effect of initiating metformin versus sulfonylureas on breast cancer risk in older women. Epidemiology 2017;28:446-454.

45. Belda-Iniesta C, Pernía O, Simó R. Metformin: a new option in cancer treatment. Clin Transl Oncol 2011;13:363-7. 
46. Jiang WG, Douglas-Jones A, Mansel RE. Expression of peroxisome-proliferator activated receptor-gamma (PPAR $\gamma)$ and the PPAR $\gamma$ coactivator, PGC-1, in human breast cancer correlates with clinical outcomes. Int J Cancer 2003;106:752-7.

47. Burstein HJ, Demetri GD, Mueller E, et al. Use of the peroxisome proliferator-activated receptor (PPAR) $\gamma$ ligand troglitazone as treatment for refractory breast cancer: a phase II study. Breast Cancer Res Treat 2003;79:391-7.

48. Wilson C. Long-term use of insulin glargine might increase the risk of breast cancer. Nat Rev Endocrinol 2011;7:499. doi: 10.1038/nrendo.2011. 112.

49. Lahmann PH, Hoffmann K, Allen N, et al. Body size and breast cancer risk: findings from the European Prospective Investigation into Cancer and Nutrition (EPIC). Int J Cancer 2004;111:762-71.

50. Ursin G, Longnecker MP, Haile RW, Greenland S. A meta-analysis of body mass index and risk of premenopausal breast cancer. Epidemiology 1995:6;137-41.

51. Yumuk PF, Dane F, Yumuk V, et al. Impact of body mass index on cancer development. J Buon 2008;13:55-9.

52. Pichard C, Plu-Bureau G, Neves-E Castro M, Gompel A. Insulin resistance, obesity and breast cancer risk. Maturitas 2008;60:19-30.

53. Jevtic M, Velicki R, Popovic M, et al. Dietary influence on breast cancer. J Buon. 2010;15:455-61.

54. Carroll PA, Healy L, Lysaght J, et al. Influence of the metabolic syndrome on leptin and leptin receptor in breast cancer. Mol Carcinog 2011;50:643-51.

55. Argolo DF, Hudis CA, Iyengar NM. The impact of obesity on breast cancer. Curr Oncol Rep 2018;20:47.

56. Gezgen G, Roach E, Kizilarslanoglu M, et al. Metabolic syndrome and breast cancer: an overview. J Buon 2012;17:223-9.

57. Seretis A, Cividini S, Markozannes G, et al. Association between blood pressure and risk of cancer development: a systematic review and metaanalysis of observational studies. Sci Rep 2019;9:8565.

58. Zhao Y, Wang Q, Zhao X, et al. Effect of antihypertensive drugs on breast cancer risk in female hypertensive patients: Evidence from observational studies. Clin Exp Hypertens 2018;40:22-27.

59. Lindgren A, Pukkala E, Tuomilehto J, et al. Incidence of breast cancer among postmenopausal, hypertensive women. Int J Cancer 2007;121:641-4.

60. Largent J, McEligot A, Ziogas A, et al. Hypertension, diuretics and breast cancer risk. J Hum Hypertens 2006;20:727-32.

61. Li CI, Malone KE, Weiss NS, et al. Relation between use of antihypertensive medications and risk of breast carcinoma among women ages 65-79 years. Cancer 2003;98:1504-13.

62. Terry MB, Perrin M, Salafia CM, et al. Preeclampsia, pregnancy-related hypertension, and breast cancer risk. Am J Epidemiol 2007;165:1007-14.

63. Fiorenza A, Branchi A, Sommariva D. Serum lipoprotein profile in patients with cancer. A comparison with non-cancer subjects. Int J Clin Lab Res 2000;30:141-5.

64. Ferraroni M, Gerber M, Decarli A, et al. HDLcholesterol and breast cancer: a joint study in northern Italy and southern France. Int J Epidemiol 1993;22:772-80.

65. Moorman PG, Hulka BS, Hiatt RA, et al. Association between high-density lipoprotein cholesterol and breast cancer varies by menopausal status. Cancer Epidemiol Biomarkers Prev 1998;7:483-8.

66. Dos Santos CR, Fonseca I, Dias S, et al. Plasma level of LDL-cholesterol at diagnosis is a predictor factor of breast tumor progression. BMC Cancer 2014;14:132.

67. Kim Y, Park SK, Han W, et al. Serum high-density lipoprotein cholesterol and breast cancer risk by menopausal status, body mass index, and hormonal receptor in Korea. Cancer Epidemiol Biomarkers Prev 2009; 18:508-15.

68. Kucharska-Newton AM, Rosamond WD, Mink PJ, et al. HDL-cholesterol and incidence of breast cancer in the ARIC cohort study. Ann Epidemiol 2008;18:671-7.

69. Agnoli C, Berrino F, Abagnato CA, et al. Metabolic syndrome and postmenopausal breast cancer in the ORDET cohort: a nested case-control study. Nutr Metab Cardiovasc Dis 2010;20:41-8.

70. Capasso I, Esposito E, Pentimalli F, et al. Metabolic syndrome affects breast cancer risk in postmenopausal women: National Cancer Institute of Naples experience. Cancer Biol Ther 2010;10:1240-3.

71. Bjørge T, Lukanova A, Jonsson H, et al. Metabolic syndrome and breast cancer in the me-can (metabolic syndrome and cancer) project. Cancer Epidemiol Biomarkers Prev 2010;19:1737-45.

72. Beaulieu LM, Whitley BR, Wiesner TF, et al. Breast cancer and metabolic syndrome linked through the plasminogen activator inhibitor-1 cycle. Bioessays 2007;29:1029-38.

73. Stern MP. Diabetes and cardiovascular disease: the "common soil" hypothesis. Diabetes 1995;44:369-74.

74. Goodwin PJ, Ennis M, Pritchard KI, et al. Fasting insulin and outcome in early-stage breast cancer: results of a prospective cohort study. J Clin Oncol 2002;20:42-51.

75. Khandekar MJ, Cohen P, Spiegelman BM. Molecular mechanisms of cancer development in obesity. Nat Rev Cancer 2011;11:886-95. 


\section{Metabolic syndrome and breast cancer patients}

Eur J Transl Myol 30 (3): xx1-xx7, 2020

76. Nieman KM, Romero IL, Van Houten B, et al. Adipose tissue and adipocytes support tumorigenesis and metastasis. Biochim Biophys Acta 2013;1831:1533-41.

77. Byers T, Sedjo R. Does intentional weight loss reduce cancer risk? Diabetes Obes Metab 2011;13:1063-72.

78. Rack B, Andergassen U, Neugebauer J, et al. The German SUCCESS C study-the first European lifestyle study on breast cancer. Breast Care (Basel). 2010;5:395-400.

79. Rock CL, Byers TE, Colditz GA, et al. Reducing breast cancer recurrence with weight loss, a vanguard trial: the Exercise and Nutrition to Enhance Recovery and Good Health for You (ENERGY) Trial. Contemp Clin Trials 2013;34:282-95.

80. Cottet V, Touvier M, Fournier A, et al. Postmenopausal breast cancer risk and dietary patterns in the E3N-EPIC prospective cohort study. Am J Epidemiol 2009; 170:1257-67.

81. Trichopoulou A, Bamia C, Lagiou P, et al. Conformity to traditional Mediterranean diet and breast cancer risk in the Greek EPIC (European Prospective Investigation into Cancer and Nutrition) cohort. Am J Clin Nutr. 2010;92:620-5.

82. Kashaki M, Masoudi Samghabadi F, Bordbar A. Effect of Fortification of Breast Milk in Conjugation with Protein Supplement on Neurodevelopment of Preterm Low Birth Weight Infants at 3 Years. Med Arch 2019;73:344-50.

83. Kashaki M, Mazouri A, Bordbar A, e al. Effect of Protein Supplementation on the Growth of Infants Weighing Less than 1,000 Grams Hospitalized on the Neonatal Intensive Care Unit of Akbar Abadi Hospital in Tehran, Iran (2015-2016). Iranian J Neonatol 2018:9:49-56.

84. Bordbar A, Mazouri A, Kashaki M, et al. Standard Multiple and Single Daily Dosingof Amikacin in Premature Infants. Iranian J Neonatol 2017;8:5764.

Submission: December, 21, 2019

Revision received: January 22, 2020

Acceptance: January 29, 2020 